\title{
MEMAHAMI KETERTARIKAN WARGA NEGARA ASING TERHADAP TRADISI PEMERCIKAN TIRTA SUCI PADA PATUNG GANESHA DI SAHASRA ADHI PURA, SONOSEWU, SUKOHARJO SEBAGAI MEDIA KOMUNIKASI ANTAR BUDAYA
}

\author{
Ivo Dimas Ageng Raditya \\ (ivodimasagengraditya52@gmail.com) \\ (Mahasiswa Ilmu Komunikasi Universitas Semarang)
}

\begin{abstract}
This research aims to determine the factors of the main attraction foreign citizen to knows the sprinkling holy water on ganesha statue tradition at Sahasra Adhi Pura, Sonosewu, Sukoharjo .

The theory used in this research adopted from Littlejohn ( 2009), external stimuli generate an internal meanings that will generate a response to the outside. Signification itself internally divided into two parts: the internal response and internal stimuli. The question in this research is the dominant factor affecting an individual's interest to get to know other cultures. The question in this research what factor has dominant affecting individual 's interest to know other cultures .

The method used is non - participatory observation and in-depth interviews using qualitative descriptive analysis. This research was conducted in Sukoharjo. With interviews by a competent speaker is a professor of philosophy and culture of Java, while sampling using purposive sampling technique .

It was concluded that the dominant factors affecting the interests of foreign citizen which are condition of community attitudes towards immigrants openness and acceptance of differences, also the effectiveness of word of mouth .
\end{abstract}

Kata Kunci : Komunikasi, Komunikasi antarbudaya, Patung Ganesa

\section{PENDAHULUAN}

Proses untuk mengenal suatu budaya tidak bisa dilakukan dalam sekejap. Salah satu caranya adalah dengan mengetahui makna simbolik yang terkandung dalam suatu ritual budaya. Dengan mengetahui makna simbolik dari suatu tradisi, berarti sudah membuka jalan untuk mengenal dan mencintai suatu budaya.

Tradisi Pemercikan Tirta Suci pada Patung Ganesha di Sahasra Adhi Pura, Sonosewu, merupakan salah satu bentuk budaya yang menjadi contoh salah satu tradisi budaya di Jawa Tengah yang berakar dari budaya Hindu. Tradisi Pemercikan Tirta Suci pada Patung Ganesha di Sahasra Adhi Pura, Sonosewu bisa dikatakan kurang dikenal dan tidak banyak masyarakat lokal Indonesia terutama di propinsi Jawa Tengah yang mengetahui tentang ritual tersebut. Tradisi Pemercikan Tirta Suci pada Patung Ganesha di Sahasra Adhi Pura, Sonosewu seharusnya dikenal oleh masyarakat Indonesia karena mempunyai potensi nilai pariwisata yang cukup tinggi. Tradisi Pemercikan Tirta Suci pada Patung Ganesha di Sahasra Adhi Pura, Sonosewu merupakan salah satu aset budaya bagi Indonesia. Kurangnya peliputan dan pengenalan tradisi ini menjadi salah satu penyebab kurang 
dikenalnya tradisi ini oleh masyarakat. Selain itu, website yang memberi informasi tentang Sahasra Adhi Pura, (http://www.sahasraadhipura.org/)

menggunakan bahasa Inggris yang membatasi penerima informasi hanya pada orang yang mengerti.

Kebudayaan , dalam proses komunikasi antar budaya tak boleh dilihat hanya sekedar adat istirahat, namun patut dipandang meliputi pertukaran persepsi tentang diri sendiri dan orang lain yang menjadi sasaran komunikasi dan bahkan persepsi dan sikap terhadap suatu objek. (Liliweri 2011:151). Selain itu cara pandang, salah satu yang mempengaruhi komunikasi antarbudaya, merupakan struktur yang dipengaruhi oleh kebudayaan yang kemudian menggerakkan atau membentuk semacam spirit bagi individu untuk menjelaskan suatu peristiwa. Karena individu merupakan bagian dari suatu budaya, maka hal itu berlaku juga pada cara pandang terhadap suatu tradisi. (Liliweri 2011:152). Pengaruh lain yang menciptakan perbedaan komunikasi pada orang yang berbeda budaya adalah perbedaan cara berpikir. Menurut Maletzke dalam Liliweri, ada perbedaan cara berpikir antarbudaya yang mempengaruhi cara berpikir individu. (Liliweri 2011:231).

Pada umumnya, perbedaan latar belakang budaya mempengaruhi penerimaan individu pada budaya baru yang memiliki latar belakang yang berbeda. sebagai contoh Perbedaan kebiasaan, pola pikir, dan pemahaman simbolik yang berbeda menjadi hal yang menghambat penerimaan individu pada budaya baru. Sedangkan pada individu yang memiliki latar belakang budaya yang sama, seharusnya lebih mudah untuk tertarik dan memahami suatu budaya. Hal itu terjadi karena setiap kebudayaan mengajarkan cara- cara tertentu untuk memproses informasi yang masuk dan keluar dari atau ke lingkungan sekeliling mereka.( Liliweri 2002:154 ) Hal tesebut sangat terlihat pada masyarakat High Context Culture ( sebagai contoh masyarakat di Asia misal Jepang, Indonesia,dll ) yang hidup ditengah budaya Low Context Culture ( sebagai cintoh masyarakat di Eropa dan Amerika ) atau sebaliknya, masyarakat Low Context Culture yang hidup di tengah budaya High Context Culture, karena akan ada tradisi atau simbol komunikasi yang tidak bisa langsung diterima oleh individu tersebut.( Liliweri 2002:155 )

Fenomena yang terjadi pada Tradisi Pemercikan Tirta Suci pada Patung Ganesha justru bertolak belakang dengan yang diharapkan. Tradisi tersebut justru lebih dikenal dengan baik oleh beberapa warga negara asing dari beberapa negara yang berbeda. Para warga negara asing itu sangat mengenal baik ritual tersebut, bahkan menghayatinya dengan baik. Latar belakang budaya yang berbeda tidak menjadi penghalang bagi warga negara asing tersebut untuk mengenal dan menghayati tradisi budaya Pemercikan Tirta Suci pada Patung Ganesha yang terdapat di Sahasra Adhi Pura, Sonosewu.

Simbol yang terdapat pada tradisi Pemercikan Tirta Suci pada Patung Ganesha di Sahasra Adhi Pura, Sonosewu bisa jadi memiliki pengaruh akan ketertarikan warga negara asing terhadap tradisi tersebut. Hal itu dapat terjadi dikarenakan perilaku individu sangat dipengaruhi oleh simbol yang disampaikan individu lain. Namun interpretasi simbol bisa berbeda tergantung dari persepsi dari masingmasing individu karena manusia memahami pengalaman mereka melalui makna-makna yang yang ditemukan dalam simbol-simbol.(Littlejohn 
2009:231). Pada akhirnya hal tersebut menjadi salah satu kemungkinan alasan utama berbedanya pemahaman masingmasing individu tentang suatu tradisi.

Penelitian ini penting untuk lebih mengenal salah satu ritual yang bisa dikatakan belum banyak dikenal oleh masyarakat. Selain itu, penelitian ini berusaha mencari penyebab ritual budaya tersebut kurang dikenal oleh masyarakat lokal dan lebih dikenal oleh beberapa warga negara asing.

\section{TINJAUAN PUSTAKA \\ Komunikasi Antar Budaya}

Studi komunikasi antar budaya adalah dapat diartikan sebagai studi yang menekankan efek kebudayan pada komunikasi ( William B. Hart dalam Liliweri 2011:8 ). Definisi yang paling sederhana adalah komunikasi antar pribadi yang dilakukan oleh mereka yang berbeda latar belakang kebudayaan. ( Liliweri 2011:9 ). Dalam pelaksanaan, dibutuhkan efektivitas agar terlaksana dengan baik. Namun efektivitas komunikasi tidak ditentukan hanya karena setiap orang sudah melakukan interaksi, relasi dan komunikasi sesuai dengan peranan tetapi juga harus menjaga keseimbangan antara kegiatan interaksi, relasi dan komunikasi diantara dua kebudayaan yang berbeda. (Liliweri 2011:258).

\section{Interaksionisme Simbolik}

Interaksionisme simbolis merupakan sebuah cara berpikir mengenai pikiran, diri sendiri, dan masyarakat yang digagas oleh George Herbert Mead. Interaksionisme Simbolis mengajarkan bahwa manusia berinteraksi satu sama lain sepanjang waktu, mereka berbagi pengertian untuk istilah-istilah dan tindakan-tindakan tertentu dan memahami kejadiankejadian dalam cara-cara tertentu pula. ( Littlejohn 2009:121). Dalam interaksionisme simbolis, makna merupakan sebuah hasil komunikasi yng penting. Pemaknaan individu merupakan hasil interaksi dengan individu lain. ( Littlejohn 2009:233 )

Mead dari Interaksionisme Simbolik, mempelajari tindakan sosial dengan mempergunakan teknik intropeksi untuk dapat mengetahui sesuatu yang melatarbrlakangi tindakan sosial tersebut dari sudut aktor dengan pengggunaan bahasa serta kemampuan belajar yang tidak dimiliki oleh binatang.

Menurut teori Interaksionisme Simbolik, fakta sosial bukanlah sesuatu yang mengendalikan dan memaksa tindakan manusia. Fakta sosial ditempatkan dalam kerangka simbolsimbol interaksi manusia. Teori ini menolak pandangan paradigma fakta sosial dan paradigma perilaku sosial (social behavior) yang tidak mengakui arti penting kedudukan individu. Padahal kenyataannya manusia mampu menciptakan dunianya sendiri. Interaksionisme Simbolik sebagai sebuah gerakan, ada untuk meneliti cara-cara manusia berkomunikasi, memusat, atau dapat membagi makna. ( Littlejohn 2009:236).

\section{Komunikasi Ritual}

Komunikasi Ritual merupakan salah satu fungsi komunikasi dan berkaitan erat dengan komunikasi efektif. Komunikasi ritual biasanya dilakukan secara kolektif. Suatu komunitas sering melakukan upacaraupacara berlainan sepanjang tahun dan sepanjang hidup. Dalam acara-acara itu orang mengucapkan kata-kata atau menampilkan perilaku-perilaku simbolik. Mereka yang berpartisipasi dalam bentuk komunikasi ritual tersebut menegaskan kembali komitmen mereka kepada tradisi keluarga, komunitas,suku, bangsa, negara, 
ideologi, atau agama mereka. ( Mulyana 2007:27).

\section{Semantic Meaning Theory}

Semantic Meaning Theory dikembangkan oleh Charles Osgood dan berhubungan dengan cara-cara mempelajari makna dan bagaimana makna tersebut berhubungan dengan pemikiran dan perilaku. (Littlejohn 2009:189).

Teori Osgood memulai dengan bagaimana individu belajar, bahwa kita memberi respons terhadap rangsangan dalam lingkungan dan membentuk sebuah hubungan rangsangan-respons. Rangsangan dari luar menghasilkan sebuah pemaknaan internalyang akan menghasilkan respon ke luar. Pemaknaan internal itu sendiri dibagi menjadi dua bagian: respon internal dan rangsangan internal. Selain merespon pada objek-objek atau pengalaman fisik, individu juga bisa merespon kata-kata dan gerak tubuh. Ketika tanda dipasangkan dengan makna, tanda tersebut akan memberikan respon yang sama atau mirip. (Littlejohn 2009:190 ).

\section{METODOLOGI PENELITIAN}

\section{Bentuk dan Strategi Penelitian}

Dalam melakukan penelitian ini, peneliti menggunakan bentuk penelitian kualitatif, metode riset studi kasus, dan pendekatan interpretatif. Penelitian kualitatif merupakan penelitian yang datanya dinyatakan dalam bentuk verbal, dan dianalisis tanpa menggunakan teknik statistik (Sangadji.

A.M \& Sopiah, 2010:26).

\section{Pendekatan interpretatif}

Pendekatan interpretatif merupakan analisis dalam menentukan dasar dan makna sosial. Menurut Max Weber dan filsuf Jerman Wilhelm Dailthey.
Penelitian interpretatif adalah melakukan telaah historis dari fenomena yang diamati. Weber mengemukakan bahwa ilmu sosial membutuhkan studi mengenai "makna" dalam setiap aktivitas sosial atau tujuan dari suatu aktivitas sosial. (Peter Burke. 2001 : 301).

\section{Metode Riset Studi Kasus}

Studi kasus adalah metode riset yang menggunakan berbagai sumber data yang bisa digunakan untuk meneliti, menguraikan dan menjelaskan secara komprehensifberbagai aspek individu, kelompok, suatu program, organisasi, atau peristiwa secara sistematis.

Robert K. Yin memberikan batasan mengenai metode studi kasus sebagai riset yang menyelidiki fenomena di dalam konteks kehidupan nyata, bilamana batas-batas antara fenomena dan konteks tak tampak dengan jelas, dan dimana multisumber bukti dimanfaatkan. (Kriyantono,2010:65).

\section{Data Primer}

Data primer merupakan sumber data penelitian yang diperoleh secara langsung dari sumber asli (Sangadji. A.M \& Sopiah, 2010:171). Peneliti melakukan observasi secara langsung dalam tradisi Pemercikan Tirta Suci pada Patung Ganesha di Saharsa Adhi Pura, Sonosewu untuk memahami ketertarikan warga negara asing.

\section{Data Sekunder}

Data sekunder merupakan data yang diperoleh dari catatan-catatan dokumen dan juga sumber dari kepustakaan, (Sangadji. A.M \& Sopiah, 2010:172). Peneliti melakukan wawancara mendalam dan memilih referensi dari beberapa buku dan website sebagai rujukan dan penguat 
data wawancara. Selain mencari data melalui sumber-sumber pustaka, peneliti juga mencoba mendalami peristiwa dengan mengikuti prosesi tradisi Pemercikan Tirta Suci pada Patung Ganesha di Saharsa Adhi Pura, Sonosewu.

\section{Teknik Sampling}

Penelitian kualitatif sangat erat kaitannya dengan faktor kontekstual sampling digunakan untuk menjaring informasi sebanyak-banyaknya. (Moleong 2005:224) Oleh sebab itu, penelitian ini menggunakan teknik purposive sampling atau sampel bertujuan.

Pada penelitian ini, sampel yang digunakan adalah warga negara asing yang telah mengenal atau mendalami tradisi Pemercikan Tirta Suci pada Patung Ganesha di Saharsa Adhi Pura, Sonosewu minimal 2 tahun.

Narasumber tersebut yaitu Mrs. Cleo ( Amerika Serikat/ telah mendalami kurang lebih selama 8 tahun ), Mrs.Melania ( Kanada/ telah mendalami kurang lebih selama 15 tahun ) , Mr.Yansen (Jerman/ telah mendalami kurang lebih selama 18 tahun ). Selain itu, peneliti juga mengadakan wawancara dengan narasumber ahli yang sangat mengetahui ritual di Sonosewu dan kehidupan Warga Negara Asing di tempat tersebut. Narasumber ahli tersebut adalah Prof. Dr. Dr. Sutomo WE, MPd ( Guru besar filsafat Jawa sekaligus peneliti pada komunitas di Sahasra Adhi Pura).

\section{Teknik Pengumpulan Data}

Observasi yang digunakan pada penelitian ini adalah observasi non partisipan. Observasi nonpartisipan merupakan metode observasi dimana peneliti hanya bertindak mengobservasi tanpa ikut terjun melakukan aktivitas seperti yang dilakukan kelompok yang diteliti baik kehadirannya diketahui atau tidak. ( Kriyantoro, 2010:112 ).

Menyesuaikan dengan bentuk penelitian kualitatif dan jenis sumber data yang dimanfaatkan, maka teknik pengumpulan data yang akan digunakan dalam penelitian ini adalah Wawancara Mendalam (Indepth Interview).

Wawancara dilakukan untuk menggali pertanyaan mengapa dan apa berdasarkan data atau informasi yang diberikan. Bersifat lentur, terbuka, tanpa panduan tertulis, dalam suasana informal dan memungkinkan pengulangan pada informan untuk memperjelas informasi sehingga menjadi lebih rinci dan mendalam mengenai subyek yang diteliti.

\section{Validitas Data}

Metode validitas data yang digunakan dalam penelitian ini adalah metode triangulasi data. Trangulasi data yang digunakan adalah triangulasi dengan sumber. Menurut Patton, triangulasi data dengan sumber berarti membandingkan dan mengecek balik derajat kepercayaan suatu informasi yang diperoleh melalui alat dan waktu yang berbeda dalam penelitian kualitatif. (Moleong 2005:330). Dalam penelitian ini, triangulasi sumber yang digunakan dicapai dengan jalan membandingkan data hasil pengamatan, hasil wawancara, dan dokumen yang berkaitan.

\section{Teknik Analisis Data}

Peneliti menggunakan analisis Interpretatif, Inti dari pemikiran interpretatif adalah melakukan telaah historis dari fenomena yang diamati. Peneliti Interpretatif menggunakan observasi partisipasi dan penelitian lapangan dalam pengumpulan datanya. Metode ini mensyaratkan peneliti untuk 
untuk ikut terlibat secara penuh pada objek penelitiannya.

Langkah pertama, peneliti akan melakukan observasi langsung dan mengumpulkan data dari observasi tersebut. Langkah Kedua, peneliti melakukan wawancara mendalam terhadap subyek penelitian. Kemudian peneliti membandingkan data yang didapat saat observasi, data dari wawancara mendalam dan dokumen yang berkaitan.

Peneliti menggunakan triangulasi data sebagai metode yang digunakan untuk memeriksa keabsahan data. Triangulasi adalah teknik pemeriksaan keabsahan data yang memanfaatkan sesuatu yang lain (Moleong 2001:330), dalam hal ini adalah membandingkan hasil pengamatan, hasil wawancara, dan dokumen yang berkaitan.

\section{HASIL DAN PEMBAHASAN}

\section{Media Komunikasi}

Internet merupakan salah satu media komunikasi yang berkembang di masa ini. Dalam sejarah teknologi komunikasi tidak ada media yang mampu menandingi Internet dalam hal pertumbuhan jumlah penggunanya. ( Morrisan, 2012:317 ). Situs website pada dasarnya tidak saja berfungsi sebagai media komunikasi yang memungkinkan perusahaan menyediakan informasi, mempengaruhi sikap, dan menciptakan kesadaran (awareness) kepada perusahaan dan produknya, namun juga berfungsi media interaktif di mana perusahaan dapat memberikan tanggapannya secara langsung terhadap pertanyaan yang diajukan konsumen. (Morrisan, 2012:321). Begitu juga dengan website www.sahasraadhipura.org, juga merupakan media informasi bagi siapapun yang ingin mengenal ritual yang terdapat di Sahasra Adhi Pura.
Namun website memiliki kelemahan. Walaupun jumlah pengguna internet meningkat terus, namun jumlahnya masih jauh di bawah jumlah penonton televisi.(Morrisan, 2012:330). Pemilik website tetap perlu mempromosikan website-nya di media promosi lain untuk menarik orang mengunjungi website-nya. Website www.sahasraadhipura.org dibuat pada tahun 2001, sehingga pada saat narasumber terlibat dalam ritual pemercikan tirta suci pada patung Ganesha, website tersebut belum ada. Sehingga untuk ketiga narasumber, website tersebut tidak menjadi daya tarik utama mereka terlibat dalam tradisi pemercikan tirta suci pada patung Ganesha. Dalam hal ini, website tidak menjadi faktor penarik bagi wrga negara asing, warga negara asing tidak menerima rangsangan sesuai teori pengartian semantik, dari adanya website, karena pada saat itu website tersebut belum ada.

\section{Kondisi Komunitas}

\section{a. Komunitas yang terbuka terhadap pendatang}

Ketiga narasumber merasa bahwa keramahan yang mereka terima dari komunitas di Sahasra Adhi Pura, membuat mereka nyaman untuk tinggal dan terlibat lebih jauh dalam setiap ritual yang terdapat di Sahasra Adhi Pura. Seluruh narasumber merasa disambut dengan istimewa. Sambutan yang di tempat asalnya hanya diberikan kepada orang - orang tertentu. Perasaan itu berlanjut ketika mereka mulai mendalami ritual yang ada di Sahasra Adhi Pura, mereka merasa dianggap sebagai keluarga, dan dapat berbicara tanpa kecanggungan. Hal tersebut menjadi rangsangan yang direspon positif oleh warga negara asing. Perlakuan yang oleh komunitas di Sahasra Adhi Pura dianggap hal yang 
biasa, dianggap sebsgai sesuatu yang istimewa. Sesuai teori pengertian semantik ( Semantic Meaning Theory), perlakuan komunitas tersebut menjadi rangsangan yang dimaknai sebagai keramahan oleh warga negara asing. Komunikasi Antarbudaya bermula dari komunikasi di antara peserta yang berbeda budaya maka menurut Candia Elliot, secara normatif komunikasi antarpribadi itu mengandalkan gaya berkomunikasi yang dihubungkan dengan nilai-nilai yang dianut orang. Nilai-nilai itu berbeda di antara kelompok etnik yang dapat menunjang dan mungkin merusak perhatian tatkala orang berkomunikasi.( Liliweri, 2011:17 ). Keramahan yang ditunjukkan oleh komunitas di Sahasra Adhi Pura menjadi nilai positif gaya komunikasi yang menciptakan sebuah komunikasi antarbudaya yang efektif. Menurut Sutomo

" Keramahan itu ada karena mereka memiliki tugas dan kewajiban untuk mengenalkan apa yang terdapat di Sahasra Adhi Pura kepada siapapun tanpa kecuali"( Sutomo. 14 Desember 2013)

Keramahan itu tidak lagi menjadi sebuah kebiasaan, tetapi mempunyai fungsi promosi untuk menarik siapapun tanpa kecuali, untuk mengenal apa yang terdapat di Sahasra Adhi Pura sebagai suatu produk budaya masyarakat Jawa.

\section{b. Penerimaan akan Perbedaan}

Komunitas di Sahasra Adhi Pura membuka diri terhadap berbagai latar belakang suku, ras, agama,atau golongan yang ingin mengenal atau belajar tentang apa saja yang terdapat di Sahasra Adhi Pura termasuk ritualritualnya. Mereka bahkan menempatkan simbol agama dan kepercayaan lain di Sahasra Adhi Pura secara setara. Ketiga narasumber merasa mereka tidak pernah dibedakan berdasar agama ataupun asal mereka. Mereka beranggapan bahwa sebenarnya setiap agama memiliki asal mula yang sama dan memiliki tujuan yang baik. Hal itu diperkuat oleh pernyataan Sutomo

" Komunitas di Sahasra Adhi Pura menganggap agama sebagai sebuah baju, yang bisa dilepas"'"( Sutomo. 14 Desember 2013)

Sebuah konsep yang tidak semua orang bisa menerima dan perlu belajar dalam waktu lama untuk bisa mengerti konsep tersebut. Warga negara asing lebih mudah menerima konsep tersebut karena keterbukaan pemikiran mereka terhadap hal baru, tidak langsung menolak walau tidak sesuai dengan pola pikir mereka. Namun hal itu tidak berlaku bagi masyarakat lokal sekitar yang sangat religius yang teguh memegang prinsip dan doktrin yang mereka pelajari terutama dari agama. Hal itu diperkuat oleh pernyataan Sutomo

" Agama seringkali yang menjadi penghalang masyarakat sekitar menerima suatu produk budaya, mereka tidak bisa menerima ritual yang terdapat di Sahasra Adhi Pura karena tidak sesuai dengan prisip agama mereka " (Sutomo. 14 Desember 2013)

Pada tradisi Pemercikan Tirta Suci terdapat doa atau mantra yang hanya dimengerti oleh komunitas tersebut, yang sulit diterima oleh masyarakt lokal karena berbeda prinsip. Setiap simbol baik berupa barang atau gerakan tubuh merupaka hasil interaksi yang dalam hal ini dari guru ke murid atau dari ndividu yang mengajarkan hal tersebut ke individu lain dalam suatu komunitas. Sesuai teori Interaksionisme Simbolik, Tindakan bersama antara dua orang atau lebih,seperti yang terjadi di dalam pernikahan, perdagangan, perang, atau kebaktian di gereja terdiri atas interhubungan (interlinkage) dari 
interaksi-interaksi yang lebih kecil. (Littlejohn.2009:232)

\section{c. Pengaktifan Word of Mouth}

Sebuah testimoni, entah menggunakan dramatisasi ataupun tidak, jika berasal dari orang dekat (significant others), mempunyai pengaruh yang besar terhadap keputusan yang diambil oleh seseorang. Tradisi Pemercikan Tirta Suci Pada Patung Ganesha merupakan salah satu bentuk komunikasi ritual yang bisa kita anggap sebagai produk budaya. Secara natural orang akan merekomendasikan produk dan layanan bila produk dan layanan itu bagus. Artinya, cerita orang lain mempunyai dampak luar biasa dan bahkan lebih besar daripada mengalaminya sendiri. (Hasan,2010:15). Itulah yang dialami oleh ketiga narasumber. Mereka tertarik untuk berkunjung ke Sahasra Adhi Pura terutama karena cerita dari orang dekat mereka. Testimoni yang dibuat oleh orang dekat bisa bersifat positif atau negatif. Menurut teori pengertian semantik Osgood, kita memberi respons terhadap rangsangan dalam lingkungan, membentuk sebuah hubungan rangsangan-respons. Osgood yakin bahwa asosiasi rangsanganrespons yang dipelajari ini bertanggung jawab dalam pembentukan makna, yang merupakan sebuah respons mental yang internal terhadap rangsangan. (Littlejohn, 2009:190). Rangsanganrespons bisa positif ataupun negatif. Yang dialami oleh ketiga narasumber adalah yang positif, sehingga mereka tertarik datang berkunjung bahkan mendalami hingga saat ini. Rangsangan yang diterima oleh warga negara asing dari orang dekat (significant others) adalah hal yang positif yang kemudian di respons secara positif, sehingga mereka juga berusaha untuk mencari tahu dan datang ke Sahasra Adhi Pura walau harus meninggalkan semua yang mereka miliki di negara asalnya. Sedangkan apa yang dialami oleh masyarakat lokal sekitar adalah yang negatif, dalam arti, mereka mendapat testimoni dari orang dekat yang mempunyai prinsip yang tidak sesuai dengan apa yang terdapat di Sahasra Adhi Pura. Sehingga mereka menjadi tidak tertarik pada apapun yang terdapat di Sahasra Adhi Pura, termasuk ritual-ritual yang terdapat di dalamnya. Berbeda dengan warga negara asing, masyarakat lokal sekitar mendapat rangsangan yang bersifat negatif. Rangsangan negatif yang muncul akibat latar belakang lingkungan yang sangat religius dan doktrin yang dipegang teguh sehingga respon yang muncul pun bersifat negatif terhadap apa yang terdapat di Sahasra Adhi Pura. Hal itu memiliki akibat masyarakat lokal sekitar kurang bisa menerima ritualritual yang terdapat di Sahasra Adhi Pura. Menurut Sutomo, " Mereka mencari tahu sendiri, setelah mereka mendapat informasi, Mereka mencari tahu dengan memanfaatkan segala hal terutama dari buku, rasa penasaran dan keingintahuan yang besar yang membawa mereka ke sini Sutomo. 14 Desember 2013).

\section{KESIMPULAN}

Observasi menunjukkan bahwa ketertarikan warga negara asing terhadap tradisi Pemercikan Tirta Suci pada patung Ganesha di Sahasra Adhi Pura, Sonosewu, Mojolaban, Sukoharjo lebih disebabkan faktor eksternal. faktor eksternal tersebut adalah media komunikasi, kondisi komunitas,dan Word of Mouth. Namun analisis membuktikan bahwa media komunikasi yang berupa website tidak memberi pengaruh yang besar terhadap ketertarikan warga negara asing 
terhadap tradisi pemercikan tirta suci pada patung Ganesha di Sahasra Adhi Pura. Faktor-faktor yang mempengaruhi ketertarikan warga negara asing terhadap tradisi pemercikan tirta suci pada patung ganesha secara dominan yaitu:

1. Faktor Kondisi Komunitas

Pengaruh yang sangat kuat mempengaruhi ketertarikan warga negara asing terhadap ritual pemercikan tirta suci pada patung Ganesha salah satunya terdapat pada kondisi komunitas yang berupa keterbukaan komunitas terhadap pendatang dan penerimaan akan perbedaan oleh komunitas Sahasra Adhi Pura yang direspon dengan baik oleh warga negara asing yang berpikiran terbuka.

2. Faktor Efektivitas Word Of Mouth

Faktor lainnya adalah penerapan Word of Mouth yang efektif yang berupa testimoni dari orang dekat yang bersifat positif yang mempengaruhi keputusan warga negara asing untuk datang, mengenal dan terlibat dalam tradisi pemercikan tirta suci pada patung Ganesha di Sahasra Adhi Pura, Sonosewu, Mojolaban, Sukoharjo.

DAFTAR PUSTAKA

Alo liliweri. 2003. Dasar-dasar komunikasi antar budaya. Yogyakarta : Pustaka Pelajar.

Ali Hasan. 2010. Marketing dari Mulut ke Mulut. Yogyakarta: Media Pressindo
Amri P. Sihotang, SS, M. Hum. 2008. Ilmu Sosial Budaya Dasar. Semarang: CV. Manunggal Karso.

Burke,Peter. 2001. Sejarah dan Teori Sosial. Jakarta : Yayasan Obor Indonesia.

Deddy Mulyana.2007.Ilmu Komunikasi. Bandung: PT Remaja Rosdakarya.

Koentjaraningrat. 1997. Masyarakat dan Kebudayaan Indonesia. Jakarta : Jambatan.

Lexy J.Moleong. 2005. Metode Penelitian Kualitatif. Bandung : Rosdakarya.

Littlejohn, Stephen W \& Karen A Foss.2009.Teori

Komunikasi.Jakarta:Salemba Humanika.

Morissan. 2010.Periklanan:Komunikasi Pemasaran Terpadu.Jakarta:Kencana

Rachmat Kriyantono.2010. Teknik Praktis Riset Komunikasi.Jakarta:Kencana.

Sangadji. E.M \& Sopiah. 2010. Metodologi Penelitian. Yogyakarta : Andi Offset.

Sahasra Adhi Pura. http://www.sahasraadhipura.org \%. akses 16 Juni 2013 pukul 20.30 WIB

Suharsimi Arikunto.1996. Prosedur Penelitian. Jakarta:Rineka Cipta 